Jurnal Ilmu-Ilmu Peternakan 25 (2): 10 - 19

ISSN: 0852-3581

E-ISSN: 9772443D76DD3

CFakultas Peternakan UB, http://jiip.ub.ac.id/

\title{
Pengaruh pemberian antibiotika saat budidaya terhadap keberadaan residu pada daging dan hati ayam pedaging dari peternakan rakyat
}

\author{
Nina Marlina $\mathrm{A}^{1}$, Elok Zubaidah ${ }^{2}$, Aji Sutrisno ${ }^{2}$ \\ ${ }^{1}$ Direktorat Mutu dan Standardisasi, Ditjen. Pengolahan dan Pemasaran Hasil Pertanian, \\ Kementerian Pertanian \\ ${ }^{2}$ Fakultas Teknologi Pertanian, Universitas Brawijaya \\ e-mail: marlinaadiyati@gmail.com
}

\begin{abstract}
The use of antibiotics in animal husbandry cannot be avoided either as an act of therapy, supportive or prevention. This study was aimed to determine the existence of antibiotic residues in broiler chicken products which were produced by poultry farm and to determine the safety level of residues in the product which was associated with a drug application and harvesting time. Thigh meat and liver samples of broiler were taken when thinning and harvesting time in poultry farm at Pamijahan- Bogor using purposive sampling method. Residue testing was conducted through bioassay screening test. Positive results were followed by a confirmatory test using HPLC. Total positive samples were detected residues reached $27.08 \%$ which included the macrolide group reached $22.92 \%$ and tetracycline group reached $4.17 \%$. These residues were found in the liver, reaching $50 \%$ of the total sample of the liver. In addition, $53.85 \%$ of the positive samples came from broiler chicken samples taken during thinning period. Macrolide antibiotics in liver samples were detected in the form of erythromycin with the level compounds between 0085 - $0702 \mathrm{ppm}$. Moreover, 90.9\% of the samples had levels exceeding MRL defined in SNI 01-6366-2000 and CAC/MRL-2-2012. Tetracycline antibiotic was detected in the form of doxycycline with the level compounds between 0-0067 ppm on thigh meat and 0-0085 ppm in the liver although these levels were still below the MRL. The residues existence was closely related to the drug dose and farmer's knowledge about withdrawal time.
\end{abstract}

Keyword: antibiotic, residue, broiler, drug dose, harvesting time

\section{PENDAHULUAN}

Tingkat produksi dan konsumsi ayam ras terutama pedaging sangat tinggi. Kabupaten Bogor merupakan salah satu sentra produksi dan pemasok produk ayam ras pedaging di Provinsi Jawa Barat, salah satunya dipasok dari Kecamatan Pamijahan. Menurut data Dinas Peternakan dan Perikanan Kabupaten Bogor (2013), di lokasi ini memiliki jumlah produksi daging ayam ras mencapai $16.198 .116 \mathrm{~kg}$ dengan populasi ternak ayam ras pedaging sebanyak 3.362.000 ekor.

Peternakan broiler umumnya rawan serangan penyakit yang disebabkan oleh virus, bakteri, parasit, jamur, lingkungan dan kekurangan salah satu unsur nutrisi (Tamalluddin, 2012). Menurut Iyo (2015), peternak 
memiliki kecenderungan lebih mengutamakan keselamatan ayam dari serangan penyakit dibandingkan pertimbangan residu obat antibiotika dan sulfa pada ayam. Rahayu (2014) menyatakan bahwa residu dapat ditemukan akibat penggunaan obatobatan, termasuk antibiotika, pemberian feed additive ataupun hormon pemacu pertumbuhan hewan. Senyawa obat yang masuk kedalam tubuh ternak tidak dapat seluruhnya diekskresi dari jaringan dan akan tertahan dalam jaringan tubuh sebagai residu. Hasil pengamatan Palupi dan Unang (2009) menunjukkan bahwa pemakaian obat dengan dosis berlebihan, pemberian dalam jangka waktu lama dan waktu henti obat yang tidak tepat menyebabkan adanya residu obat dalam karkas maupun organ visera. Dengan demikian menurut Palupi dan Unang (2009) serta Palupi (2012) menyatakan perlu perhatian lebih terhadap penggunaan obat pada ayam melalui sediaan obat dan pakan yang terjamin mutu dan jumlahnya.

Pemeriksaan residu secara kualitatif pada 6 provinsi di Indonesia menunjukkan $4,1 \%$ sampel paha ayam dan $2,7 \%$ sampel hati dinyatakan positif golongan tetrasiklin (Werdiningsih dkk., 2013). Sampel daging ayam yang berasal dari Kabupaten Bogor terdeteksi positif mengandung residu antibiotika golongan aminoglikosida dan tetrasiklin (BPMSPH, 2013). Kontaminasi residu juga sering terjadi di luar negeri diantaranya hasil survei di Nigeria ditemukan residu obat hewan dalam jaringan ayam yaitu 59 dari 178 broiler $(33,1 \%)$ dan oksitetrasiklin merupakan obat yang paling banyak digunakan. Studi di Kroasia, rata-rata kadar streptomycin dalam daging $44,14 \mu \mathrm{g} / \mathrm{kg}$ dan dalam susu $15,57 \mu \mathrm{g} / \mathrm{kg}$, kadar tetrasiklin dalam daging $1,62 \mu \mathrm{g} / \mathrm{kg}$ dan dalam susu 1,5 $\mu \mathrm{g} / \mathrm{kg}$ (Kabir et al.,
2004; Vragovic et al., 2011). Donkor et al (2011) melaporkan bahwa prevalensi residu obat hewan di Ghana sebanyak $21,1 \%$ dalam sampel produk asal hewan.

Konsumsi pangan asal hewan seperti daging ayam yang mengandung residu antibiotika akan menimbulkan gangguan kesehatan. Bahaya residu obat hewan dapat berupa bahaya langsung dalam jangka pendek seperti alergi, gangguan pencernaan, gangguan kulit, anafilaksis dan hipersensitifitas, serta bahaya tidak langsung yang bersifat jangka panjang seperti resistensi mikrobiologi, karsinogenik, mutagenik, teratogenik dan gangguan reproduksi (Ruegg, 2013; Seri, 2013; Singh et al., 2014).

Kehidupan ternak dan keamanan produk yang dihasilkan dipengaruhi beberapa faktor praproduksi seperti tanah, air, udara, pakan, obat hewan, bahan kimia dan penyakit ternak (Bahri dkk., 2005). Salah satu upaya agar kegiatan praproduksi mampu menghasilkan produk ternak yang aman dan bermutu maka harus mengikuti teknik budidaya ayam pedaging yang baik (Good Farming Practices/ GFP) sebagaimana tercantum dalam Peraturan Menteri Pertanian Nomor 31/Permentan/OT.140/2/2014 tentang Pedoman budi daya ayam pedaging dan ayam petelur yang baik (Kementerian Pertanian, 2014).

Deteksi keberadaan residu antibiotika pada produk asal hewan perlu didukung dengan proses penelusuran balik (traceability) terhadap proses budidaya (penerapan good farming practices) yang diterapkan peternak untuk mengetahui penyebab terjadinya residu tersebut sehingga tindakan perbaikan yang akan dilakukan bisa tepat sasaran dan sesuai harapan. Penelitian ini bertujuan untuk 
mengetahui keberadaan residu antibiotika pada produk ayam broiler yang dihasilkan peternakan rakyat dikaitkan dengan aplikasi obat yang diberikan saat proses budidaya dan waktu panen yang dilakukan peternak serta tingkat keamanan dari pangan tersebut.

\section{MATERI DAN METODE}

\section{Materi dan alat}

Bahan yang digunakan yaitu sampel daging paha dan hati ayam, kuman uji (Bacillus stearothermophilus ATCC 7953, Bacillus cereus ATCC 11778, Bacillus subtillis ATCC 6633, Kocuria rizophila (MicrococcusIuteus) ATCC 9341, pepton, bacto agar, yeast extract, dextrose, beef extract, glukosa, larutan baku pembanding, TCA $20 \%$, metanol, asam oksalat, ACN, dapar Mcllvaine, amonium asetat, heksan, air distilasi, deionized water, buffer kalium phosfat dan buffer phosfat. Peralatan yang digunakan meliputi peralatan gelas, evaporator, sentrifuse, vortex, penangas air, timbangan analitik, pipet, mini kolom C-18, filter PTFE 0,45 $\mu \mathrm{m}$ $13 \mathrm{~mm}$ dan HPLC Agilent 1100 series.

\section{Metode}

Metode yang digunakan dalam penelitian ini meliputi observasi lapang, pengambilan sampel dan pengujian sampel di laboratorium. Penentuan lokasi sampling berdasarkan jumlah populasi dan produksi ayam broiler tertinggi di wilayah Kabupaten Bogor dan diperoleh Kecamatan Pamijahan sebagai lokasi penelitian. Observasi lapang dilakukan melalui wawancara dan pengisian kuesioner terkait dengan penerapan GFP, aplikasi pemberian obat, waktu panen dan pemahaman peternak.

Pengambilan sampel ayam broiler dilakukan secara purposive sampling terhadap peternakan rakyat di kecamatan tersebut yang bermitra dengan perusahaan yang sama sehingga diperoleh 48 sampel daging paha dan hati ayam dari 3 peternak rakyat yang diambil dalam 2 periode yaitu saat penjarangan dan saat panen. Pada saat budidaya, ternak mendapatkan imbuhan Doxerin+ yang mengandung antibiotika doksisiklin dan eritromisin serta Moxacol Plus yang mengandung antibiotika amoksisiklin. Para peternak mendapatkan imbuhan tersebut dari perusahaan mitra.

Pengujian residu dilakukan melalui uji skrining dan uji konfirmasi. Pada uji skrining digunakan kuman uji yang spesifik untuk masing-masing golongan antibiotika yaitu Bacillus stearothermophilus ATCC 7953 untuk golongan penisilin, spora Bacillus cereus ATCC 11778 untuk golongan tetrasiklin, spora Bacillus subtillis ATCC 6633 untuk golongan aminoglikosida, vegetatif Kocuria rizophila (MicrococcusIuteus) ATCC 9341 untuk golongan makrolida. Sebanyak $1 \mathrm{ml}$ biakan kuman uji dicampur dengan $100 \mathrm{ml}$ media yang telah dicairkan, untuk media $B$. stearothermophilus ATCC 7953 ditambahkan 2,5\% larutan dextrose $2 \%$. Selanjutnya dipipet $8 \mathrm{ml}$ media yang telah mengandung kuman uji atau spora dan dimasukkan kedalam setiap cawan petri sesuai dengan jenis golongan antibiotika dan dilakukan ulangan triplo. Larutan sampel yang sudah dihomogenkan diambil $75 \mu \mathrm{l}$ lalu diteteskan pada kertas cakram, kemudian dimasukkan kedalam media tersebut. Larutan baku pembanding diteteskan sebagai kontrol positif. Selanjutnya cawan tersebut diinkubasi selama 16 jam-18 jam, untuk golongan makrolida dan aminoglikosida pada temperatur $36^{\circ} \mathrm{C} \pm 1{ }^{\circ} \mathrm{C}$, golongan tetrasiklin pada temperatur $30^{\circ} \mathrm{C} \pm 1^{\circ} \mathrm{C}$, 
dan golongan penisilin pada temperatur $55^{\circ} \mathrm{C} \pm 1^{\circ} \mathrm{C}$. Hasil uji dinyatakan positif jika terbentuk daerah (zona) hambatan dari tepi kertas cakram yang ditetesi sampel dan dinyatakan negatif jika tidak terbentuk zona hambatan (Badan Standardisasi Nasional, 2008).

Golongan antibiotika yang positif terdeteksi kemudian ditelusuri jenis senyawa antibiotikanya berdasarkan obat yang diberikan saat budidaya dan diuji secara kuantitatif melalui uji konfirmasi. Tahapan uji ini yaitu ekstraksi, pemurnian, identifikasi dan kuantifikasi sebagai berikut:

1) Golongan tetrasiklin

Sampel ditimbang $5 \mathrm{~g}$, dihomogenkan lalu ditambah $2 \mathrm{ml}$ TCA 20\% dan $15 \mathrm{ml}$ dapar Mcllvaine. Selanjutnya dikocok lalu sentrifugasi selama 10 menit pada kecepatan $4000 \mathrm{rpm}$. Ulangi tahapan tersebut pada endapan hasil sentrifugasi. Supernatan yang diperoleh dimasukkan dalam mini kolom C-18 yang telah diaktifasi lalu dialirkan $3 \mathrm{ml}$ metanol $5 \%$ dan $3 \mathrm{ml}$ metanol p.a. Eluet yang diperoleh dievaporasi lalu ditambah larutan fase gerak dan disaring. Larutan lalu diinjeksikan ke dalam HPLC dengan kondisi kecepatan alir $1.2 \mathrm{ml} / \mathrm{menit}$, kolom C-18, detektor UV-Vis 365 $\mathrm{nm}$ dan menggunakan fase gerak berupa asam oksalat $0,01 \mathrm{M}$ dan campuran ACN-metanol (70:30).

2) Golongan makrolida

Sampel ditimbang $2 \mathrm{~g}$, ditambah 5 $\mathrm{ml}$ ACN lalu dihomogenkan. Selanjutnya disentrifugasi pada suhu $5^{\circ} \mathrm{C}$ selama 10 menit dengan kecepatan $3000 \mathrm{rpm}$. Ulangi tahapan tersebut pada endapan hasil sentrifugasi. Supernatan ditambahkan $5 \mathrm{ml}$ heksan lalu vortex selama 10 menit. Lapisan atas dibuang kemudian larutan dievaporasi. Ekstrak kering ditambah larutan fase gerak lalu disaring. Larutan lalu diinjeksikan kedalam HPLC dengan kondisi kecepatan alir $0,8 \mathrm{ml} /$ menit, kolom C- 18 , detektor UV-Vis $280 \mathrm{~nm}$ dan menggunakan fase gerak berupa campuran amonium asetat $0,01 \mathrm{M}$ dan $\mathrm{ACN}$ (20:80).

\section{HASIL DAN PEMBAHASAN}

Sasaran utama dari studi ini yaitu untuk mengetahui dan menelusuri keberadaan residu dari obat antibiotika yang diberikan selama proses budidaya pada daging paha dan hati ayam broiler yang dihasilkan serta tingkat keamanan dari produk tersebut. Hasil pemeriksaan secara kualitatif menunjukkan bahwa 13 dari 48 sampel positif mengandung residu dan golongan antibiotika yang terdeteksi yaitu makrolida dan tetrasiklin. Sampel hati yang positif makrolida mencapai 45,83\% (11 dari 24 sampel hati). Sampel yang positif tetrasiklin meliputi sampel hati $4,17 \%$ (1 dari 24 sampel hati) dan sampel daging paha 4,17\% (1 dari 24 sampel daging paha). Sampel positif tersebut $53,85 \%$ berasal dari sampel ayam broiler yang diambil saat penjarangan.

Keberadaan residu antibiotika pada sampel daging paha dan hati ayam terkait erat dengan pemberian imbuhan pada saat proses budidaya. Para peternak mendapatkan obat antibiotika dari pihak perusahaan mitra untuk pencegahan dan pengobatan penyakit pada broiler yang terdiri dari Doxerin+ dan Moxacol Plus. Komposisi Doxerin+ terdiri dari doksisiklin 10\% dan eritromisin 20\%, masing-masing merupakan jenis antibiotika golongan tetrasiklin dan makrolida. Moxacol Plus mengandung antibiotika amoksisilin yang merupakan salah satu golongan penisilin. Berdasarkan uji skrining, sampel terdeteksi positif mengandung residu antibiotika golongan makrolida 
dan tetrasiklin sedangkan golongan penisilin terdeteksi negatif. Terdeteksinya residu golongan tetrasiklin dan makrolida pada sampel dipengaruhi oleh dosis dan waktu henti obat yang diterapkan peternak. Berdasarkan hasil observasi dan wawancara diketahui bahwa imbuhan Moxacol Plus diberikan pada saat ayam berumur antara 4-14 hari sedangkan Doxerin+ diberikan pada saat ayam berumur antara 23-31 hari. Dengan demikian jarak waktu antara pemberian Moxacol Plus dengan waktu panen baik saat penjarangan maupun umur panen cukup lama (13-18 hari) sehingga residu amoksisiklin kemungkinan besar sudah tereliminasi. Residu imbuhan Doxerin+ masih tersisa pada produk dapat dikarenakan waktu henti obat yang cukup pendek yaitu 0-2 hari pada saat penjarangan dan 4-7 hari pada saat umur panen.

Residu antibiotika golongan tetrasiklin terdeteksi pada sampel daging paha dan hati ayam dari peternak 1 yang diambil pada saat penjarangan. Hasil uji konfirmasi golongan tetrasiklin menunjukkan bahwa jenis senyawa golongan tetrasiklin yang terdeteksi yaitu doksisiklin. Residu doksisiklin pada daging paha mencapai $0,067 \mathrm{ppm}$ sedangkan pada hati mencapai 0,085 ppm. Jumlah ini masih dibawah BMR yang diatur dalam SNI 01-6366:2000 yaitu $0,1 \mathrm{ppm}$ dan standar Codex CAC/MRL 2-2012 yaitu 0,2 ppm. Residu doksisiklin dalam hati lebih tinggi dibandingkan dalam daging paha. Gambaran distribusi doksisiklin menunjukkan seluruh sediaan doksisiklin yang telah lulus uji potensi lebih banyak terdistibusi ke ginjal, paru dan hati daripada otot paha (Werdiningsih dkk., 2014). Hasil penelitian Anadon et al. (1994) menunjukkan bahwa konsentrasi doksisiklin akan hilang perlahan dan akan berada pada atau dibawah level toleransi obat dalam jaringan dalam waktu 5 hari setelah pemberian. Kromatogram uji konfirmasi sampel daging paha dan hati positif doksisiklin dapat dilihat pada Gambar 1 dan Gambar 2.

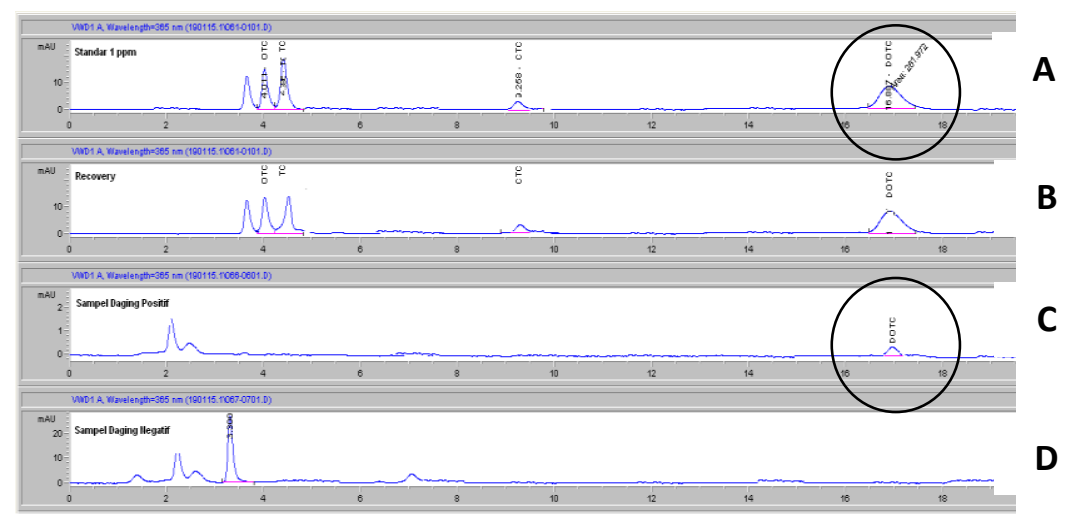

Gambar 1. Kromatogram sampel daging paha positif residu Doksisiklin. Kromatogram A: Standar Oksitetrasiklin (OTC) RT 4.011; Standar Tetrasiklin (TC) RT 4.389; Standar Klortetrasiklin (CTC) RT 9.258; Standar Doksisiklin (DOTC) RT 16.887; Kromatogram B: Recovery; Kromatogram C: Sampel daging paha positif mengandung residu Doksisiklin pada RT 16.789; Kromatogram D: Sampel daging negatif mengandung residu golongan Tetrasiklin. 


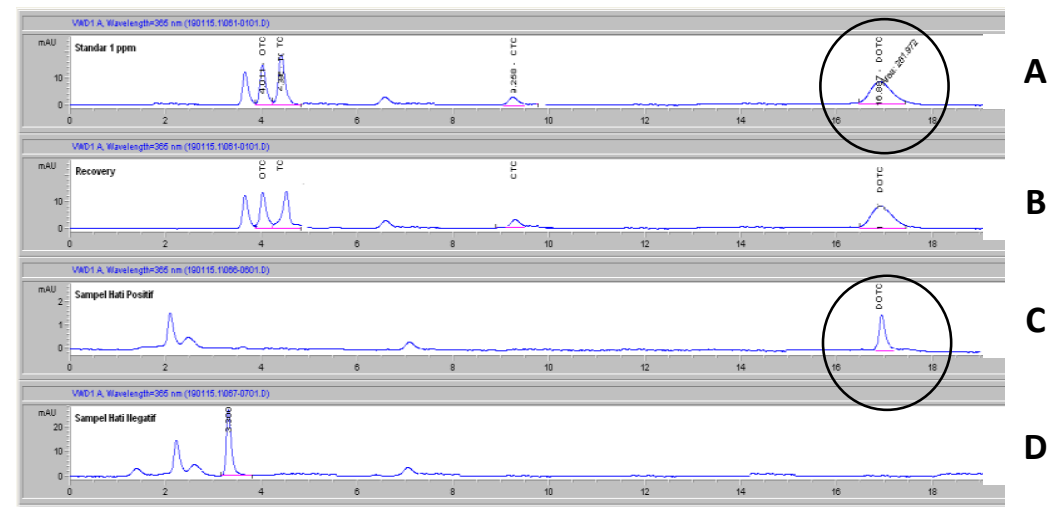

Gambar 2. Kromatogram sampel hati positif residu Doksisiklin. Kromatogram A: Standar Oksitetrasiklin (OTC) RT 4.011; Standar Tetrasiklin (TC) RT 4.389; Standar Klortetrasiklin (CTC) RT 9.258; Standar Doksisiklin (DOTC) RT 16.887; Kromatogram B: Recovery; Kromatogram C: Sampel hati positif mengandung residu Doksisiklin pada RT 16.832; Kromatogram D: Sampel hati negatif mengandung residu golongan Tetrasiklin.

Hasil uji konfirmasi golongan makrolida menunjukkan bahwa jenis senyawa golongan makrolida yang terdeteksi yaitu eritromisin. Residu ini terdeteksi pada sampel hati ayam yang berasal dari peternak 1 dan peternak 3 . Kadar residu ini pada sampel hati ayam peternak 1 yang diambil saat penjarangan yaitu 0-0,173 ppm, sedangkan pada sampel hati ayam yang diambil saat umur panen yaitu antara 0,160-0,702 ppm. Pada peternak 3, kadar eritromisin yang terdeteksi pada sampel hati ayam yang diambil pada saat penjarangan yaitu antara 0,121 $0,320 \mathrm{ppm}$, sedangkan yang diambil saat umur panen memiliki kadar residu antara 0,085-0,127 ppm. Berdasarkan data tersebut, $90,9 \%$ sampel memiliki kadar residu melebihi BMR eritromisin pada produk asal hewan yang diatur dalam SNI 01-6366:2000 maupun standar Codex CAC/MRL 2-2012 yaitu $0,1 \mathrm{ppm}$. Berdasarkan data tersebut terlihat bahwa kadar residu eritromisin dalam sampel hati ayam yang diambil dari peternak 1 berbeda dengan sampel yang diambil dari peternak 3 . Hal ini dapat disebabkan perbedaan dosis dan waktu henti obat yang dilakukan masing-masing peternak. Peternak 1 memberikan imbuhan Doxerin+ dengan dosis $250 \mathrm{~g} / 300 \mathrm{~L}$ air minum selama 3 hari berturut-turut untuk 3500 ekor atau asupan per ekornya sekitar 0,714 ppm sedangkan pada peternak 3 diberikan dosis $375 \mathrm{~g} / 1000 \mathrm{~L}$ air minum selama 3 hari berturut-turut untuk 3500 ekor atau asupan per ekornya sekitar 0,321 ppm. Berdasarkan data tersebut terlihat bahwa residu eritromisin banyak ditemukan di hati. Menurut Suarez dan Richard (2009), basa eritromisin diserap baik oleh usus kecil bagian atas, aktivitasnya menurun karena obat dirusak oleh asam lambung. Adanya makanan juga menghambat penyerapan eritromisin. Eritromisin mengalami pemekatan dalam jaringan hati. Kromatogram uji konfirmasi sampel hati positif eritromisin dapat dilihat pada Gambar 3.

Berdasarkan Direktorat Jenderal Peternakan dan Kesehatan Hewan (2014) di dalam Indeks Obat Hewan Indonesia 2014 disebutkan bahwa waktu henti obat eritromisin dan doksisiklin yaitu 5 hari. Menurut 
Murdiati (1997), terlewatinya waktu henti obat pada saat ternak dipotong diharapkan residu obat sudah tidak ditemui atau berada dibawah batas maksimum residu yang diatur dalam standar sehingga produk aman dikonsumsi. Jika dibandingkan dengan data yang diperoleh, kadar residu pada sampel yang diambil saat umur panen seharusnya mengalami penurunan dibandingkan kadar residu pada sampel yang diambil saat penjarangan seperti halnya kadar residu eritromisin pada sampel hati yang diambil dari peternak 3 karena pada saat umur panen memiliki waktu henti obat sudah sesuai dengan rekomendasi yaitu 5 hari. Namun pada peternak 1 justru sebaliknya, hal ini dapat disebabkan dosis yang diberikan lebih tinggi dan ada kemungkinan peternak 1 memberikan obat kembali pada saat mendekati umur panen. Secara garis besar kondisi masing-masing peternakan dan kaitannya terhadap keberadaan residu antibiotika pada produk yang dihasilkan dapat dilihat pada skema seperti Gambar 4.

Berdasarkan kondisi di lapangan, sarana maupun teknik budidaya yang diterapkan peternak masih sederhana, manajemen pengelolaan dan sumberdayanya pun masih terbatas. Selain masalah dosis obat yang belum sesuai anjuran dan rendahnya kepatuhan terhadap waktu henti obat (withdrawal time), peternakan rakyat belum sepenuhnya menerapkan cara budidaya ayam ras pedaging yang baik terutama terkait 1) sanitasi, desinfeksi dan kebersihan lingkungan kurang berjalan baik; 2) teknik penyimpanan sarana produksi belum sesuai; 3) pencatatan kegiatan (recording) tidak berjalan; 4) minimnya penanganan fasilitas pekerja; dan 5) kurangnya pembinaan dan pengawasan dari instansi terkait.

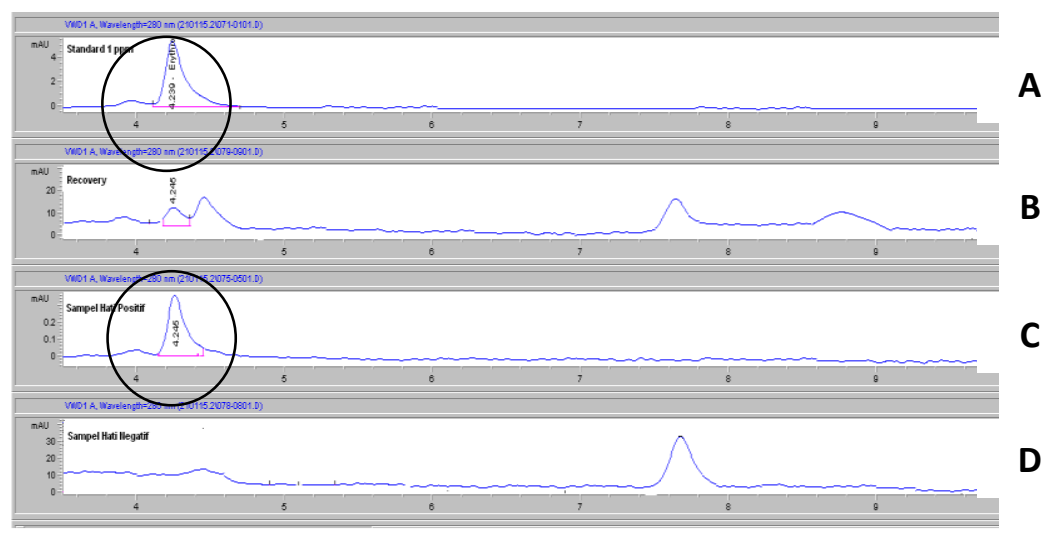

Gambar 3. Kromatogram sampel hati positif residu Eritromisin. Kromatogram A: Standar Eritromisin RT 4.239; Kromatogram B: Recovery RT 4.245; Kromatogram C: Sampel hati positif mengandung residu Eritromisin pada RT 4.245; Kromatogram D: Sampel hati negatif mengandung residu Eritromisin. 


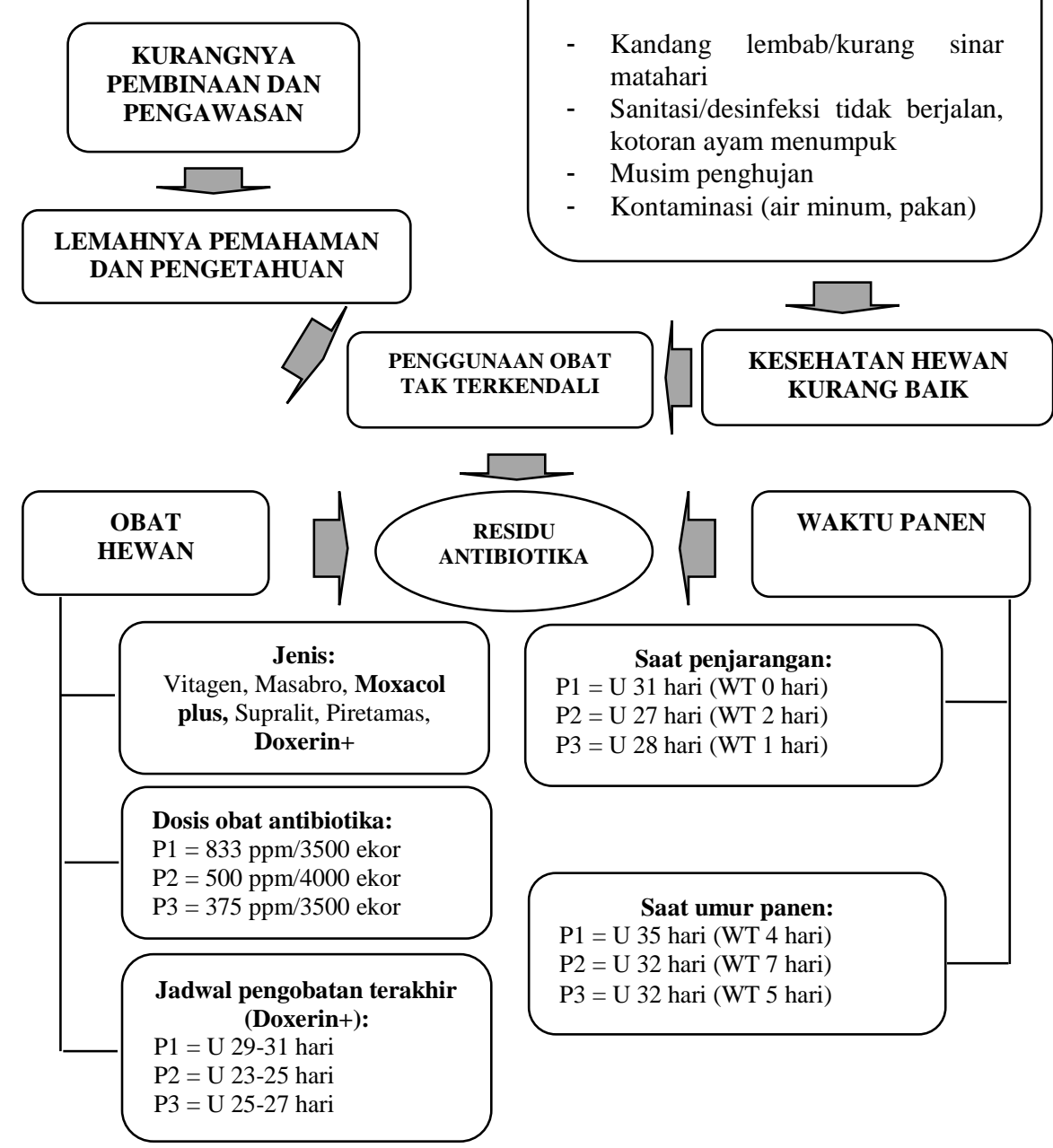

Keterangan:

$\mathrm{P} 1=$ Peternak 1; $\mathrm{P} 2=$ Peternak 2; $\mathrm{P} 3=$ Peternak 3; $\mathrm{U}=$ umur; $\mathrm{WT}=$ withdrawal time (waktu henti obat). Dosis antibiotika diberikan 3 hari berturut-turut.

Gambar 4. Gambaran beberapa kondisi peternak yang mempengaruhi keberadaan residu antibiotika

\section{KESIMPULAN}

Pemberian obat antibiotika saat budidaya masih meninggalkan residu pada daging paha dan hati ayam broiler yaitu mencapai $27,08 \%$ dari total sampel (13 dari 48 sampel). Residu antibiotika yang terdeteksi yaitu antibiotika golongan tetrasiklin dan makrolida. Residu tersebut banyak terdeteksi pada organ hati yaitu 50\% dari total sampel hati (12 dari 24 sampel), sedangkan sampel daging paha yang terdeteksi hanya $4,17 \%$ dari total sampel daging paha (1 dari 24 sampel). Sampel yang terdeteksi tersebut $53,85 \%$ berasal dari ayam broiler yang diambil saat penjarangan. Eritromisin merupakan antibiotika golongan makrolida yang terdeteksi dalam sampel hati dengan kadar residu berkisar 0,085-0,702 ppm. Sepuluh dari 11 sampel hati yang positif tersebut memiliki kadar residu eritromisin diatas BMR yang ditetapkan dalam 
SNI 01-6366-2000 dan CAC/MRL-22012 yaitu 0,1 ppm. Doksisiklin merupakan antibiotika golongan tetrasiklin. Residu antibiotika ini terdeteksi dalam sampel daging paha dengan kadar antara 0-0,067 ppm sedangkan dalam sampel hati berkisar antara 0-0,085 ppm. Kadar tersebut masih dibawah standar BMR baik yang diatur dalam SNI 01-6366-2000 maupun CAC/MRL-2-2012 yaitu masing-masing $0,1 \mathrm{ppm}$ dan 0,2 ppm. Berdasarkan hasil tersebut, sampel daging paha dan hati ayam dari peternakan rakyat berpotensi tidak aman untuk dikonsumsi sehingga perlu ditingkatkan pembinaan dan pengawasan dari instansi terkait agar pemahaman peternak semakin baik.

\section{DAFTAR PUSTAKA}

Anadon, A., Martinez-Larranaga, M. R., Diaz, M. J., Bringas P., Fernandez, M. C., FernandezCruz, M. L., Iturbe, J dan Martinez, M. A. 1994. Pharmacokinetics of doxyxycline in broiler chickens. Avian Pathology. 23:79-90.

Bahri, S., E. Masbulan dan A. Kusumaningsih. 2005. Proses praproduksi sebagai faktor penting dalam menghasilkan produk ternak yang aman untuk manusia. Jurnal Litbang Pertanian. 24 (1).

Badan Standardisasi Nasional. 2008. SNI 7424:2008, Metode uji tapis (screening test) residu antibiotika pada daging, telur dan susu secara bioassay. Jakarta.

Balai Pengujian Mutu dan Sertifikasi Produk Hewan (BMPSPH). 2013. Statistik hasil pengujian produk hewan Tahun 20122013. Ditjen Peternakan. Kementerian Pertanian.
Dinas Peternakan dan Perikanan Kabupaten Bogor. 2013. Buku data peternakan 2013. Pemerintah Kabupaten Bogor. Dinas Peternakan dan Perikanan. Bogor.

Direktorat Jenderal Peternakan dan Kesehatan Hewan. 2014. Indeks obat hewan Indonesia IOHI Edisi IX 2014. Ditjen Peternakan dan Kesehatan Hewan. Kementerian Pertanian. Jakarta.

Donkor, E. S., Mercy, J. N., Sammy, C. K. T., Nicholas T. K. D. D., Elizabeth, B., dan Michael OluTaiwo. 2011. Investigation into the risk of exposure to antibiotic residue contaminating meat and egg in Ghana. Food Control. 22:869-873.

Iyo. 2015. Peternak, penyakit bakteri dan antibiotika. Majalah Infovet Online.

http://www.majalahinfovet.com/ 2007/10/peternak-penyakitbakteri-dan.html. Diakses 27 Maret 2015.

Kabir, J., V. J. Umoh., E. Audu-okoh., J. U. Umoh., dan J. K. P. Kwaga. 2004. Veterinary drug use in poultry farms and determination of antimicrobial drug residues in commercial eggs and slaughtered chicken in Kaduna State, Nigeria. Food Control. 15:99-105.

Kementerian Pertanian. 2014. Peraturan Menteri Pertanian Nomor: 31/Permentan/OT.140/2/2014 tentang Pedoman Budi Daya Ayam Pedaging dan Ayam Petelur yang Baik. Kementerian Pertanian. Jakarta.

Murdiati, T. B. 1997. Pemakaian antibiotika dalam usaha peternakan. WARTAZOA 6 (1). 
Palupi, M. F., Min, R., dan Unang, P. 2009. Farmakokinetik parasetamol dalam plasma ayam (Gallus domesticus). Balai Besar Pengujian Mutu dan Sertifikasi Obat Hewan. Bogor.

Palupi, M. F. 2012. Pentingnya penilaian risiko (risk assessment) dalam penggunaan antibiotika pemacu pertumbuhan (antibiotic growth promotor). Balai Besar Pengujian Mutu dan Sertifikasi Obat Hewan. Bogor.

Ruegg, P. L. 2013. Antimicrobial residues and resistance: Understanding and managing drug usage on dairy rarms. University of WI, Dept. of Dairy Science, Madison.

Rahayu, I. 2014. Prinsip pengobatan. Husbandry Corner. http://imbang.staff.umm.ac.id/?p $=81$. Diakses 6 September 2014.

Suarez, A. F dan Richard, E. 2009. Erythromycin.

www.mhlw.go.jp/shingi/2009/04/ dl/s0414-5i.pdf. Diakses 16 Maret 2015.

Seri, H. I. 2013. Introduction to veterinary drug residues : hazards and risks. Workshop of veterinary drug residues in food derived from animal 26-27 $7^{\text {th }}$ May 2013. Department of Animal Health and Surgery. College of Veterinary Medicine. Sudan University of Science and Technology.
Singh, S., Sanjay, S., Neelam, T., Nitesh, K., dan Ritu, P. 2014. Antibiotic residues: a global challenge. An International Journal of Pharmaceutical Science. Pharma Science Monitor. 5 (3):184-197.

Tamalluddin, F. 2012. Ayam broiler, 22 hari panen lebih untung. Penebar Swadaya. Jakarta.

Vragovic, N., Davorin, B., dan Bela, N. 2011. Risk assessment of streptomycin and tetracycline residues in meat and milk on Croatian market. Food and Chemical Toxicology. 49:352355.

Werdiningsih, S., Unang, P., Novida, A., Ambarwati dan Eli, N. 2013. Pengkajian residu tetrasiklin dalam paha, hati dan telur ayam pada beberapa Provinsi di Indonesia. Buletin Pengujian Mutu Obat Hewan No. 19 Tahun 2013. Balai Besar Pengujian Mutu dan Sertifikasi Obat Hewan. Bogor.

Werdiningsih, S., Nina, T. Y., Nurhidayah dan Eli, N. 2014. Profil distribusi beberapa sediaan doksisiklin pada organ/jaringan ayam broiler. Buletin Pengujian Mutu Obat Hewan No. 21 Tahun 2014. Balai Besar Pengujian Mutu dan Sertifikasi Obat Hewan. Bogor. 